Rakenteiden Mekaniikka (Journal of Structural Mechanics)

Vol. 50, No 3, 2017, pp. 239 - 243

https://rakenteidenmekaniikka.journal.fi/index

https://doi.org/10.23998/rm.64914

(c) The author(s) 2017.

Open access under CC BY-SA 4.0 license.

\title{
Large bore engine connecting rod fretting analysis
}

\author{
Antti Mäntylä ${ }^{1}$, Jussi Göös, Anton Leppänen and Tero Frondelius
}

Summary. A detailed contact analysis of a large connecting rod was performed to evaluate the fretting risk in the big end. Simulation was carried out in Abaqus considering all relevant boundary conditions, such as assembly loads, housing machining and dynamics from a flexible multibody simulation with elastohydrodynamic bearings. Being one of the most important variables, the local coefficient of friction (COF) and its evolution is calculated during the solution by using a subroutine in Abaqus. The model is validated by strain gauge measurements in a running engine. The resulted friction coefficient distribution matches well with the findings from a laboratory engine. The described methodology increases the accuracy of the fretting damage prediction by using a more realistic friction coefficient definition.

Key words: Wärtsilä, connecting rod, fretting, fatigue, friction, contact mechanics

Received 15 June 2017. Accepted 12 August 2017. Published online 21 August $201 \%$.

\section{Introduction}

The performance of medium speed four-stroke engines has been increasing a lot during the past few years. Due to high utilization of the plain fatigue limits [9] of the materials and large amount of clamped sub-assemblies in the engine, fretting fatigue [5] evaluation has become extremely important. There are certain fretting-related design requirements which need to be tracked efficiently during new development projects. This is done by using the Wärtsilä Digital Design Platform [8].

Fretting damage in dry metal contacts is caused by small cyclic sliding movement under contact pressure. Adhesion can take place and induce cracks that stay usually hidden in the contact. In case of crack growth, the failure can be unexpected and catastrophic. The challenge in the fretting is that the phenomenon itself is a complex interaction of friction, wear and fatigue $[3,13]$. Propagation of fretting-induced cracks can be predicted by using fracture mechanics $[2,12]$, but there is no generalized theory to predict surface damage. The energy-based Ruiz fretting damage parameter (FDP) [11] and its enhancement [14] can be used to predict potential locations of the fretting damage, but these theories are sensitive to COF, which makes it difficult to define any damage thresholds. In a fretting contact, the COF evolves over time, depending on the local contact conditions.

Extensive fretting tests have been carried out in Tampere University of Technology (TUT), and the results show that a very high COF, above 1.0, can be achieved with

\footnotetext{
${ }^{1}$ Corresponding author. antti.mantyla@wartsila.com
} 
quenched and tempered steel [6]. It has been also seen that the adhesion spots form in an early state at the same time when the COF evolves [6]. Therefore it is clear that there is a link between friction, adhesion and possible crack nucleation. In the component level simulations, the COF is even more important as it usually dominates the amount of slip that is the key variable causing the fretting damage. To meet these challenges, the simulation methodology that is based on local evolution of COF is described in this paper and used in the contact analysis of a large connecting rod.

\section{Methods}

The contact analysis of a large bore engine connecting rod is performed by using nonlinear finite element analysis (FEA) driven by the acceleration and bearing loads from flexible multibody simulation (MBS) in a time domain $[4,10]$.

Elastohydrodynamic bearing models are used in the MBS to solve the oil film pressure in the sliding bearings [1]. As the big end housing needs to be cylindrical after the connecting rod is assembled, it is machined after the bolt tightening. The same procedure needs to be considered in FEA to ensure a realistic contact pressure between the bearing shells and the housing. Also the local evolution of COF and possible wear are simulated by using the UINTER subroutine in Abaqus. In the subroutine, contact condition is checked and forces are calculated at each node during the solution. Nodal friction coefficient and possible material removal due to wear are stored in solution dependent variables. The simulation process is illustrated in Fig. 1.

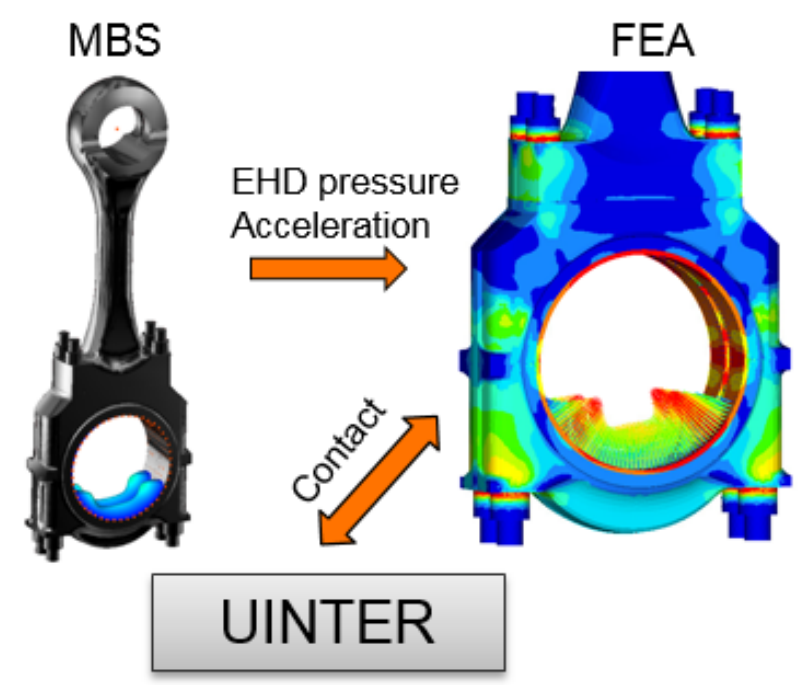

Figure 1. Connecting rod contact simulation workflow.

Motivated by the results in [6], the frictional energy dissipation is used as a driver to the evolution of COF. The latest tests in TUT have revealed that, in stick conditions, the maximum stable COF is about 0.5 [7], which makes it reasonable to use that as a limiting value in the simulation. The starting value of the COF is 0.1 due to fact that the bearing shells are assembled with some oil on the surfaces. Ten engine cycles are simulated to guarantee a slow enough evolution of COF to capture the history dependency of the contact conditions. The formula for the COF evolution is as follows

$$
\mu_{n, i+1}=\mu_{n, i}+k \cdot \Delta s_{n, i} \cdot \tau_{n, i}
$$


where $i$ is a simulation increment, $n$ is a node, $\Delta s$ is a slip increment, $\tau$ is a shear traction and $k$ is a constant regulating the speed. As the COF is considered to be isotropic, incremental slip and shear traction has the same direction, and COF can only increase. The purpose of the method is not to capture high COF that is not stable, but to simulate stabilized situation. Also the possible wear is calculated by introducing a nodal contact gap $h$ calculated as

$$
h_{n, i+1}= \begin{cases}h_{n, i}+w \cdot\left|\Delta s_{n, i}\right| \cdot p_{n, i}, & \text { if } p_{n, i}>p_{\text {lim }} \\ h_{n, i}, & \text { otherwise }\end{cases}
$$

where $w$ is a constant, $p$ is a nodal contact pressure and $p_{\text {lim }}$ is a limit values above which the wear occurs. It is assumed that the wear process is slower than the COF evolution so the wear calculation is activated after the COF distribution has been stabilized. If slip occurs in the stabilized situation, wear starts to evolve.

\section{Results and discussion}

A laboratory test was performed with the strain gauge arrangement in the bearing shell and the housing. As shown in Fig. 2C, the simulated stresses in the housing and the bearing shell match well with the measurements in the running engine. The engine was run at a remarkably higher speed than designed for this specific connecting rod and therefore fretting damage was expected. As can be seen in $2 \mathrm{~A}$ and $\mathrm{B}$, the $\mathrm{COF}$ of friction has increased to 0.5 in the same area where fretting damage can be found in the real component. The bearing shell gets stuck in this situation and therefore no further wear occurs as also observed in reality.

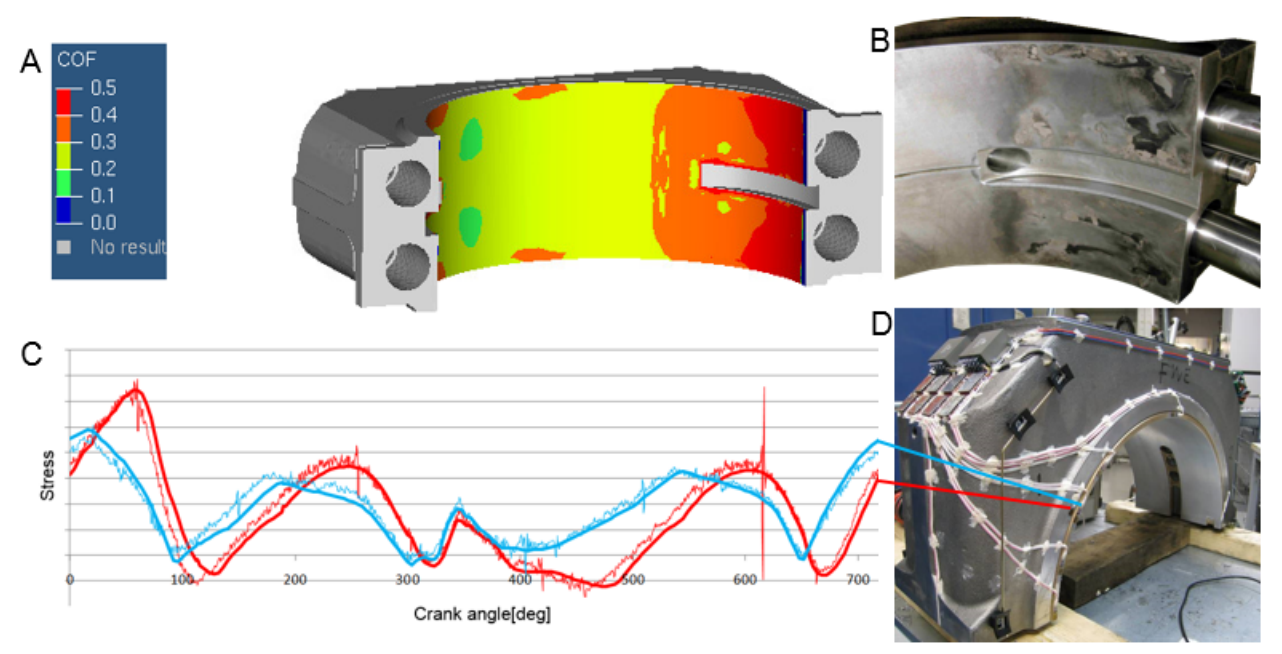

Figure 2. (A) Simulated COF distribution, (B) fretting damage in laboratory, (C) simulated and measured stress comparison, (D) strain gauge setup.

Further fracture mechanic studies could be made to predict if the component would fail later, but usually it is not worth doing as the fretting damage is not allowed in the first place. This kind of simulations can be further used in design optimization to ensure the reliability of components. 


\section{References}

[1] Liang Bai, Teemu Kuivaniemi, Pasi Halla-aho, and Tero Frondelius. Elasto hydro dynamic simulation of the slider bearing. Rakenteiden Mekaniikka, 50(3):283-286, 2017. URL https://doi.org/10.23998/rm.64922.

[2] M.C. Baietto, E. Pierres, A. Gravouil, B. Berthel, S. Fouvry, and B. Trolle. Fretting fatigue crack growth simulation based on a combined experimental and XFEM strategy. International Journal of Fatigue, 47(0):31 - 43, 2013. ISSN 0142-1123. URL https://doi.org/10.1016/j.ijfatigue.2012.07.007.

[3] J. L. Chaboche and P. M. Lesne. A non-linear continuous fatigue damage model. Fatigue \& Fracture of Engineering Materials \& Structures, 11(1):1-17, 1988. ISSN 1460-2695. URL http://doi.org/10.1111/j.1460-2695.1988.tb01216.x.

[4] Jussi Göös, Anton Leppänen, Antti Mäntylä, and Tero Frondelius. Large bore connecting rod simulations. Rakenteiden Mekaniikka, 50(3):275-278, 2017. URL https://doi.org/10.23998/rm.64658.

[5] David Hills and David Nowell. Mechanics of fretting fatigue. Kluwer Acadmic Publishers, Dordrecht, 1994. ISBN 0-7923-2866-3.

[6] Jouko Hintikka, Arto Lehtovaara, and Antti Mäntylä. Fretting-induced friction and wear in large flat-on-flat contact with quenched and tempered steel. Tribology International, 92:191 - 202, 2015. ISSN 0301-679X. URL https://doi.org/10.1016/j . triboint.2015.06.008.

[7] Jouko Hintikka, Arto Lehtovaara, Tero Frondelius, and Antti Mäntylä. Tangential traction instability in fretting contact below fully developed friction load. Rakenteiden mekaniikka, 50(3):175-178, 2017. URL https://doi.org/10.23998/rm.65105.

[8] Juho Könnö, Hannu Tienhaara, and Tero Frondelius. Wärtsilä digital design platform. Rakenteiden Mekaniikka, 50(3):234-238, 2017. URL https://doi.org/10. $23998 / \mathrm{rm} .64621$.

[9] Jussi Korhonen, Juha Kuoppala, Miikka Väntänen, Joona Vaara, Mikko Turunen, Panu Kämäräinen, Jarkko Laine, Aulis Silvonen, and Tero Frondelius. Qt-steel very high cycle fatigue testing with ultrasonic. Rakenteiden Mekaniikka, 50(3):304-308, 2017. URL https://doi.org/10.23998/rm.65059.

[10] Teemu Kuivaniemi, Antti Mäntylä, Ilkka Väisänen, Antti Korpela, and Tero Frondelius. Dynamic gear wheel simulations using multi body dynamics. Rakenteiden Mekaniikka, 50(3):287-291, 2017. URL https://doi.org/10.23998/rm.64944.

[11] C Ruiz, PHB Boddington, and KC Chen. An investigation of fatigue and fretting in a dovetail joint. Experimental Mechanics, 1984. URL https://doi.org/10.1007/ BF02323167.

[12] Joona Vaara, Antti Mäntylä, and Tero Frondelius. Brief review on high-cycle fatigue with focus on non-metallic inclusions and forming. Rakenteiden Mekaniikka, 50(3): 146-152, 2017. URL https://doi.org/10.23998/rm.65048. 
[13] Miikka Väntänen, Joona Vaara, Jukka Aho, Jukka Kemppainen, and Tero Frondelius. Bayesian sequential experimental design for fatigue tests. Rakenteiden Mekaniikka, 50(3):201-205, 2017. URL https://doi.org/10.23998/rm.64924.

[14] J Vidner and E Leidich. Enhanced ruiz criterion for the evaluation of crack initiation in contact subjected to fretting fatigue. Internal Journal of Fatigue, 29(9):2040-2049, 2007. URL https://doi.org/10.1016/j.ijfatigue.2007.02.010.

Antti Mäntylä, Jussi Göös, Anton Leppänen and Tero Frondelius

Wärtsilä

Järvikatu 2-4

65100 Vaasa

antti.mantyla@wartsila.com, jussi.goos@wartsila.com, anton.leppanen@wartsila.com, tero.frondelius@wartsila.com 